\title{
LENISQUILLA CALIFORNIENSIS, A NEW SPECIES OF STOMATOPOD CRUSTACEAN
}

\author{
JOHN A. CUNNINGHAM,,$^{1,3}$ CEES H. J. HOF, ${ }^{2}$ AND SIMON J. BRADDY ${ }^{3}$ \\ 'Department of Earth and Ocean Sciences, University of Liverpool, 4 Brownlow Street, Liverpool L69 3GP, United Kingdom, \\ $<$ John.Cunningham@liverpool.ac.uk>; '2Zoological Museum Amsterdam, Faculty of Science, University of Amsterdam, PO Box 94766, \\ 1090 GT Amsterdam, The Netherlands; and 'BDepartment of Earth Sciences, University of Bristol, Wills Memorial Building, Queen's Road, \\ Bristol BS8 1RJ, United Kingdom
}

\section{INTRODUCTION}

$\mathrm{S}$ TOMATOPODS, OR mantis shrimps, are malacostracan crustaceans. Known as "lean, mean, killing machines" (Watling et al., 2000, p. 1), modern stomatopods are obligate carnivores, feeding exclusively on live prey (Schram, 1986). Characteristically, their second thoracic appendages are enlarged to form powerful, raptorial claws. Modern stomatopods are divided into two broad functional groups based on the shape and usage of their raptorial claws: 'spearing' and 'smashing' stomatopods (Caldwell and Dingle, 1976).

Spearing stomatopods are found in each of the seven stomatopod superfamilies (see Ahyong and Harling, 2000; Ahyong, 2001) and spear their prey, which is usually soft-bodied, with the spined terminal forelimb segment (dactyl) of the raptorial claw. Smashing forms are found within four families of the superfamily Gonodactyloidea (although the family Coronodidae within the superfamily Lysiosquilloidea has adaptations for both spearing and smashing). These stomatopods feed mainly on armoured prey such as crabs and gastropods.

There has been a large body of work on the taxonomy, functional morphology and behavior of extant stomatopods. At least 450 extant species have been described (Ahyong, 2001), but the fossil record of the group is poor; less than 30 fossil species from the Mesozoic through the Tertiary, and only four from the Paleozoic have been described (Hof and Briggs, 1997; Jenner et al., 1998). The occurrence of any new fossil material is therefore significant as it contributes important new data to help understand the evolutionary history of the group. In particular, important information can be gained regarding the evolution of spearing and smashing raptorial claws. It should be noted that, in spite of the general paucity of fossil stomatopods, the Miocene of California has previously yielded seven stomatopod specimens. Hof and Schram (1998) have suggested that this abundance, coupled with the demonstration by Hof and Briggs (1997) that stomatopods have relatively high preservation potential in comparison to other unmineralized invertebrates, suggests that the poor fossil record is probably due to collection and identification biases rather than decay and degradation.

In this note, a well-preserved spearing stomatopod from the collections of the Museo Civico di Storia Naturale, Milan, Italy (MSNM i 11824) is described as a new species within the superfamily Squilloidea, whose phylogeny has recently been studied by Ahyong (2005). The specimen is most likely to originate from the Miocene of California. The morphological terminology, measurements, and indices employed follow Manning (1969).

SYSTEMATIC PALEONTOLOGY

Class Malacostraca Latreille, 1806

Subclass HOPLOCARIDA Calman, 1904

Order STOMATOPODA Latreille, 1817

Suborder UNIPELTATA Latreille, 1825

Superfamily SQUILLOIDEA Latreille, 1802

Family SQUILLIDAE Latreille, 1802

Genus LENISQUILLA Manning, 1977

Type species. - L. lata (Brooks, 1886)

Other species._L. gilesi (Kemp, 1911); L. californiensis n. sp.
Diagnosis.-Eye elongate; cornea bilobed, broader than stalk, width less than 0.3 times carapace length. Carapace with or without anterolateral spines; median carina absent; with intermediate, reflected marginal and reduced lateral carinae, distinct anteriorly and posteriorly only; posterolateral margin rounded. Raptorial claw with four to six teeth; carpus dorsal carina undivided; merus without outer interferodistal spine. Mandibular palp three-segmented. Maxillipeds one through four with epipod. Pleopod one endopod in adult males with posterior endite; hook process with distal point. In thoracic somites five through seven lateral process a single slender spine directed anterolaterally, slightly inclined ventrally. Pleomeres one to five submedian carinae variably present. Telson submedian teeth with fixed apices; prelateral lobe indistinct; dorsolateral surface without supplementary longitudinal carinae. Telson ventral surface with short postanal carina. Uropodal protopod inner margin with slender spines. (Emended from Ahyong, 2001).

\section{LENISQUILLA CALIFORNIENSIS new species} Figures 1, 2

Diagnosis.-A moderately sized stomatopod, approximately 60 mm long. Small, narrow, flask-shaped eyes; rounded ocular scales. Elongated antennular somite. Carapace with no anterolateral spines, anterolateral portion not sloping posteriorly, rounded posterolateral angles and narrowing rapidly anteriorly. Dactyl of raptorial claw armed with four to five teeth. First five pleomeres with longitudinal pairs of submedian, intermediate and lateral carinae. Telson broader than long with distinct median carina, three pairs of marginal teeth and eight to ten intermediate denticles on each side.

Description.-Specimen MSNM i 11824 is a well-preserved, moderatelysized stomatopod approximately $60 \mathrm{~mm}$ in length (Fig. 1.1) showing the cephalic region (including eyes, ophthalmic somite, antennular somite and appendages, and antennal appendages), the carapace and basal part of the rostral plate, the raptorial claws, the fifth through eighth thoracic somites, the first four pleomeres and part of the fifth, and the telson.

The specimen has an ophthalmic somite bearing stalked eyes. These eyes are not preserved in great detail but their outline is visible in places; they are small and flask-shaped (i.e., short and stout with a straight inner margin of the anterior third, and a convex outer margin). The cornea (Fig. 2.1, 2.2) is narrower than the maximum width of the eyestalk (Fig. 2.1, 2.2). The ocular scales appear fused into a single plate (Fig. 2.1, 2.2). The anterior margin of the opthalmic somite projects forward, although the apex is not preserved.

The antennular somite is somewhat elongated (Fig. 2.1, 2.2). The antennular processes (Fig. 2.1, 2.2) are patchily preserved but their outlines are visible; they are slender and quadrate in form. The first segments of each of the antennules (Fig. 2.1,2.2) are stretched out anteriorly and are vertically juxtaposed beneath the eyes. The antennules are approximately equal in width to the eyes except for at their base where they are widened. Here their outer margins are visible as curved structures lying outside the outer margins of the eyes. The antennal appendages are clearly preserved on the right hand side of the specimen. The second segment of the antennal protopod is apparent. Both segments of the antennal exopod are also visible. Only the proximal part of the antennal scale (Fig. 2.1, 2.2) is preserved. Only the first two segments of the antennal endopod are present.

Only the basal part of the rostral plate is visible, its basal width is approximately one third that of the anterior margin of the carapace. However, 


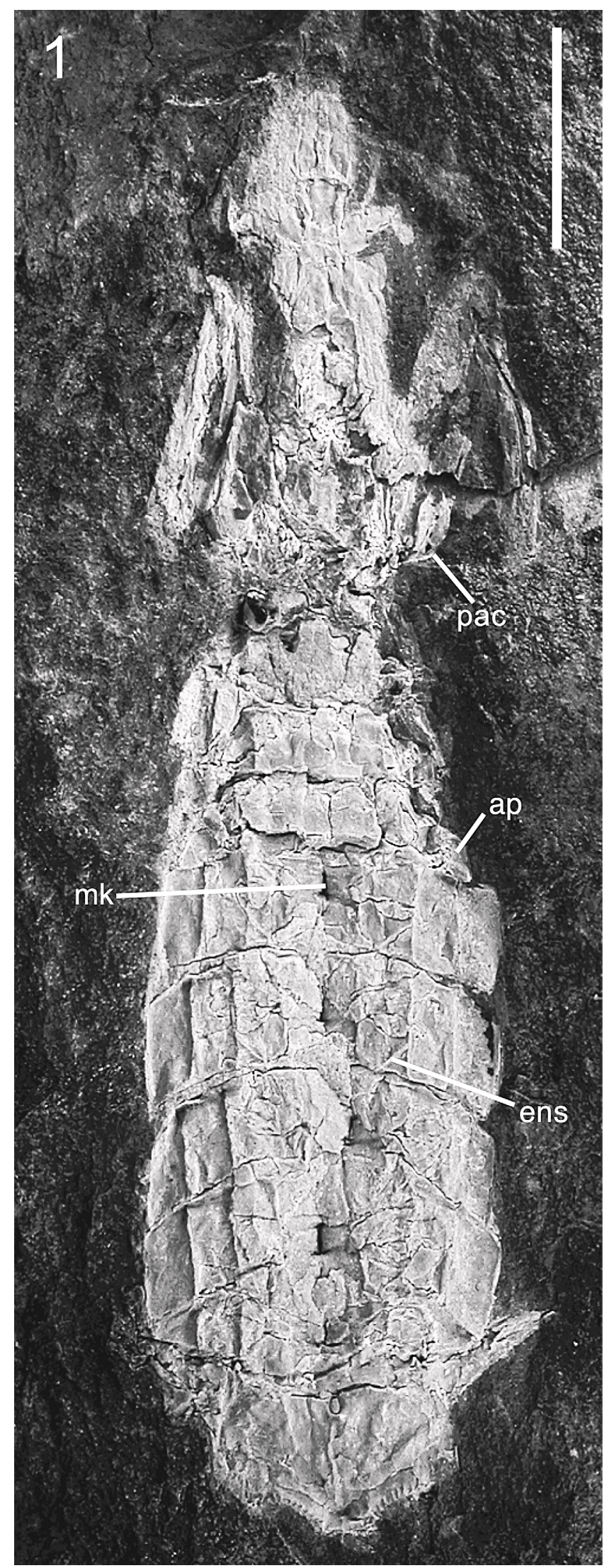

2
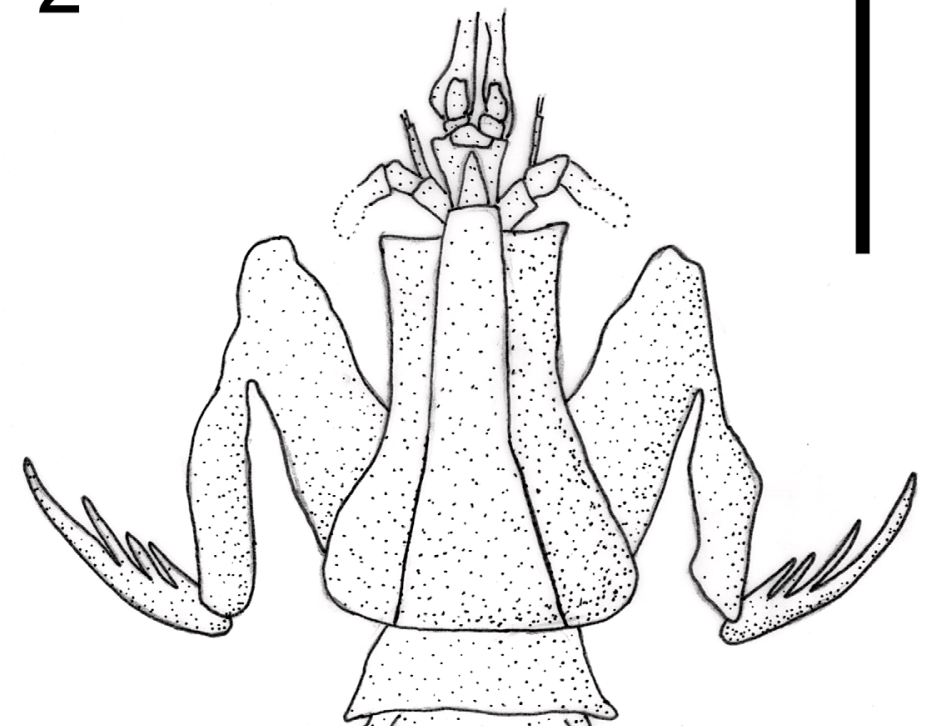

FIGURE 1-Lenisquilla californiensis n. sp. 1, Holotype MSNM i 11824; ap = anterolateral plate, ens = endophragmal skeleton, mk = median keel, pac $=$ posterolateral angle of carapace; scale bar $=10 \mathrm{~mm}$. 2, Dorsal reconstruction. Scale bar $=10 \mathrm{~mm}$. 

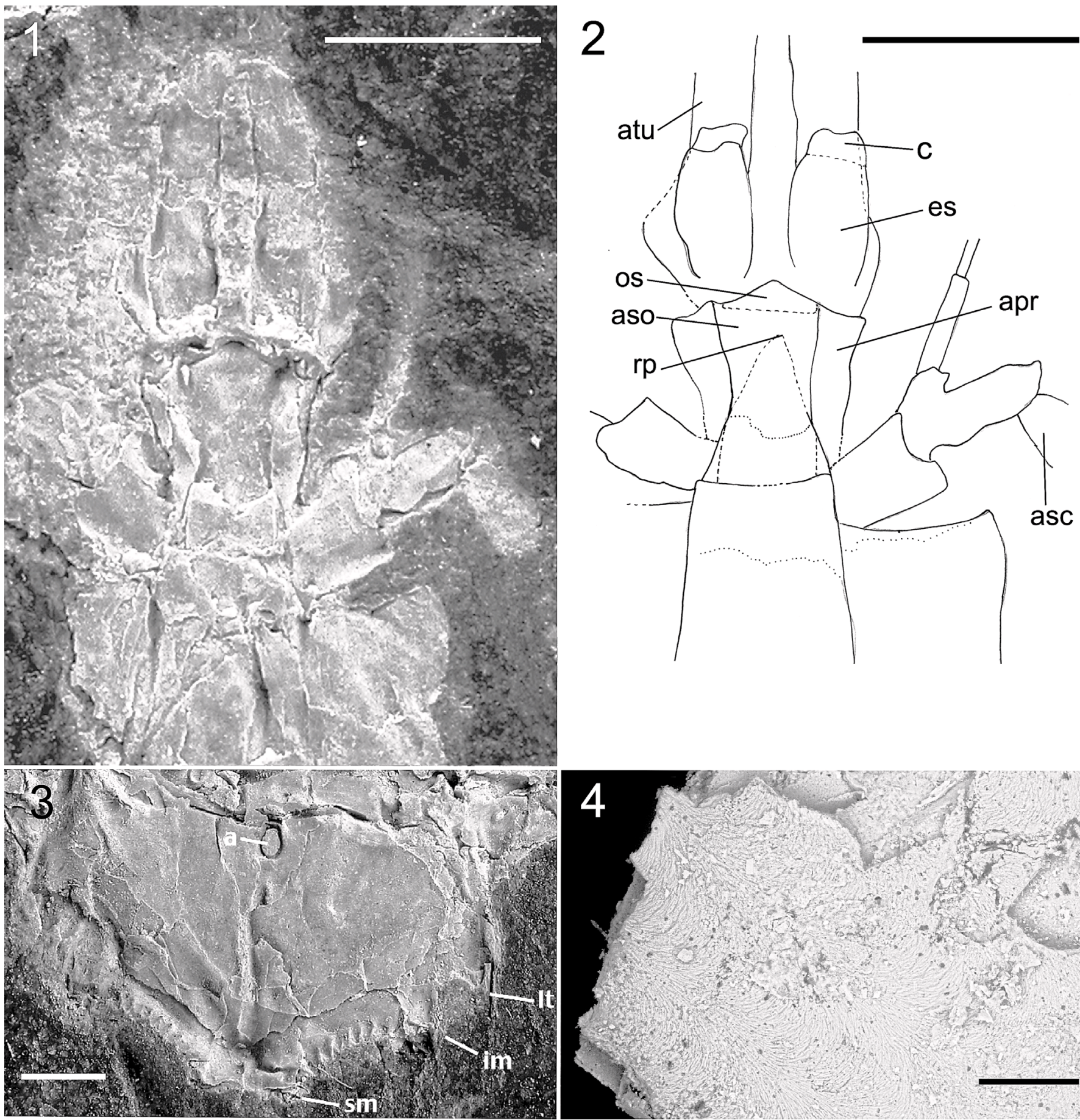

FIGURE 2-Lenisquilla californiensis $\mathrm{n}$. sp. holotype MSNM i 11824; 1, Cephalic region. Scale bar $=5 \mathrm{~mm}$. 2, Interpretive drawing of the cephalic region, apr $=$ antennular process, atu $=$ antennule, asc $=$ antennal scale, aso $=$ antennular somite, $\mathrm{c}=$ cornea, es $=$ eye stalk, os $=$ ocular scale, $\mathrm{rp}=$ rostral plate (arrow points to inferred apex); dashed lines represent inferred biological features, dotted lines represent cracks or artefacts. Scale bar $=5 \mathrm{~mm}$. 3, Telson, a $=$ anus, $\mathrm{im}=$ intermediate tooth, $1 \mathrm{t}=$ lateral tooth, $\mathrm{sm}=$ submedian tooth. Scale bar $=2 \mathrm{~mm}$. 4, Backscattered electron image of a section of cuticle from the pleon. Scale bar $=100 \mu \mathrm{m}$.

the antennular somite appears to preserve a 'scar' marking the former position of the rostral plate (Fig. 2.1, 2.2), suggesting that the plate had an elongate triangular shape with a rounded apex. The carapace is only preserved in patches. Despite this, its outline can be clearly traced; it has rounded posterolateral angles (Fig. 1.1) and narrows strongly anteriorly. The specimen lacks anterolateral spines and the anterolateral portion of carapace does not slope posteriorly. The specimen bears no dorsal ornamentation of the carapace.

The merus, carpus, propodus, and dactyl of each raptorial claw are preserved. The dactyls have been compressed against the propodi. The dactyls are curved and are approximately two thirds as long as the carapace; four teeth, including the terminal tooth are visible.

The fifth through eighth thoracic somites including their lateral processes are preserved. These processes are all single (i.e., not bilobed). The lobes of the fifth and sixth somites have become detached. Whereas spines are preserved on their posterolateral margins, their direction is unclear as the lobes may have rotated. The lobes of the seventh thoracic somite are preserved in situ; they form posterolaterally directed spines. The lobes of the eighth somite are covered by the anterolateral plates of the first pleomere. No evidence of carination of these somites is preserved. 
The first four pleomeres and part of the fifth are preserved, although the sixth is missing. Their preservation is remarkable as dorsal, ventral, and internal features have all been preserved. The tergites exhibit submedian, in termediate, and lateral carinae. It is not possible to determine whether the pleon has a median carina because ventral structures are preserved in the central region. The first pleomere also preserves the anterolateral plates, which project from the anterior margin of this somite and lie over the eighth thoracic somite (Fig. 1.1). The ventral structures preserved in the pleon are the median keel (Fig. 1.1), visible in all the preserved pleomeres, and the coxal openings, that are visible on somites 3 and 4. Parts of the endophragmal skeleton can also be seen (Fig. 1.1) running diagonally across the pleon. With the exception of part of the basal prolongation on the right hand side, the uropods are not visible.

The telson is short and stout (Fig. 2.3). It is almost twice as wide as it is long. The telson has three pairs of teeth; the submedian, intermediate and lateral teeth (Fig. 2.3). Eight intermediate denticles are visible (though more may be present-see Discussion) on the concave margin between the submedian and intermediate teeth on either side. The anus is visible as an oval structure in the central anterior part of the telson (Fig. 2.3). Below the anus a structure that may represent either the dorsal median carina or the ventral post-anal carina is clearly preserved. The telson also displays some additional ornament (see discussion).

Etymology.-The species is named for California, believed to be the source of the holotype.

Type--Holotype, MSNM i 11824, deposited in the collections of the Museo Civico di Storia Naturale, Milan, Italy.

Occurrence.-The precise locality of the specimen is unknown. When the Museo Civico di Storia Naturale, Milan acquired the specimen from a private collection, the locality was recorded only as "Miocene, California". As the preservation is so remarkable, it was hoped that workers familiar with the local geology would recognize it as being similar to previously discovered fossils. A number of paleontologists, geologists, museum curators, and commercial fossil dealers familiar with Californian material were sent color images of the specimen (see Acknowledgments), but none were familiar with the mode of preservation. Perhaps the most likely candidate is the late Miocene Monterey Formation, which crops out over a large area of California. This formation contains mudstone (Rowell, 1981) and well-preserved marine fossils including decapods (Rathbun, 1932; Waggoner, personal commun., 2000) and stomatopods (Hof and Schram, 1998; Groves, personal commun., 2001). However, none of these fossils seem to have the same level of preservation as MSNM i 11824; they do not, for example, preserve cuticle microstructure. It should be noted that there is a possibility that the locality and age information is incorrect and that the specimen is neither Miocene nor from California.

Discussion.-A dorsal reconstruction of this species (Fig. 1.2) is provided. Difficulties were encountered reconstructing the dactyls due to their preservation. While four teeth can be seen on the right dactyl, poor preservation at the proximal end means that it may have had five teeth. However, space constraints limit the maximum number of teeth to five.

A similar problem was encountered when reconstructing the number of intermediate denticles on the telson. While eight denticles are visible on each side, their preservation at the ends of the rows is poor, suggesting there may have been more. However, the number of denticles possible is limited by the amount of available space, meaning that there could not have been more than ten denticles on each side.

When reconstructing the ornament of the telson it is difficult to distinguish true ornament from apparent ornament caused by distortion of the telson. If a structure appears symmetrically on either side of the telson it was reconstructed as a real feature. Unfortunately, this is rarely the case and it seems that the left hand side of the telson has been distorted, perhaps by the uropods lying underneath.

The presence of longitudinal carination on the pleon, in combination with a telson with a distinct median carina and more than four intermediate denticles, indicates that specimen MSNM i 11824 belongs to the superfamily Squilloidea (see Manning, 1980, 1995; Ahyong 2001). This superfamily contains only a single family, the Squillidae (see Ahyong, 2005).

Various features exhibited in specimen MSNM i 11824 indicate an affinity with the extant genera Clorida, Cloridina, Neclorida, and Lenisquilla rather than any of the other described genera within Squillidae. These are: 1) a carapace that narrows rapidly anteriorly and has rounded posterolateral angles; 2) dactyls with four to five teeth; and 3) a stout telson. These genera form a clade within the Clorida-group clade of Ahyong (2005) (the latter is equivalent to the 'small eyed' squillids of Kemp (1913) and Manning (1968)). The genera Clorida, Cloridina, and Neclorida are very similar in appearance and are distinguished only by eye morphology. Ahyong (2001) suggests that the distinction between these three genera is gradational and that there may be a case for synonymy into a single genus Clorida. Lenisquilla also closely resembles these genera, but is distinguished by the absence of dorsolateral ornamentation and by the presence of fixed, rather than movable, submedian teeth on the telson.

The absence of dorsolateral ornament on the telson in MSNM i 11824 allows it to be excluded from the genera Clorida, Cloridina and Neclorida but not from Lenisquilla. The specimen differs from the two described species of Lenisquilla as follows: 1) absence of anterolateral spines on the carapace; 2) anterolateral part of carapace not sloping posteriorly; and 3) eyestalks are narrower than those of Lenisquilla, resembling instead those of Cloridopsis. These differences are considered insufficient to merit the erection of a new genus and the specimen is thus described as a new species of Lenisquilla.

Measurements.- Total length of MSNM i $1182461 \mathrm{~mm}$ (estimate based on reconstruction of the anterior margin of the rostral plate). Carapace length $14 \mathrm{~mm}$ (estimate based on reconstruction of the location of the posterior margin of the carapace). Rostral plate basal width $3 \mathrm{~mm}$. Raptorial claw dactyl length $10 \mathrm{~mm}$. Pleon width $16 \mathrm{~mm}$ (measured at fourth pleomere). Telson width $12 \mathrm{~mm}$. Telson length $7 \mathrm{~mm}$.

Taphonomy.-The taphonomy of the specimen seems remarkable with the cream-colored specimen preserving evidence of cuticle microstructure (Fig. 2.4) and contrasting strongly with the dark mudstone matrix. This aspect is worthy of further study and will be dealt with fully elsewhere.

\section{ACKNOWLEDGMENTS}

We thank G. Teruzzi (Museo Civico di Storia Naturale, Milan) for bringing the specimen to our attention. We are grateful to J. van Arkel (Zoological Museum Amsterdam) for photography, R. Earl (University of Bristol) for providing information based on a preliminary examination of the specimen, and S. Davis and P. Hawes (School of Chemistry, University of Bristol) for assistance with SEM. We thank the following people for responding to requests for locality information: L. I. Anderson (National Museums of Scotland), C. Burns, T. A. Demere (San Diego Natural History Museum), R. M. Feldman (Kent State University), H. Filkorn (National History Museum of Los Angeles County), L. Groves (California State University), K. Johnson (National History Museum of Los Angeles County), W. B. Leatham (California State University), A. R. Milner, L. Nesbitt (Burke Museum, University of Washington), L. R. Saul (National History Museum of Los Angeles County), F. R. Schram (University of Washington), T. Smith (University of California, San Diego), B. Waggoner (University of Central Arkansas) and Geological Enterprise Incorporated, Oklahoma. We thank P. J. Orr (University College Dublin), S. T. Ahyong (Australian Museum), F. R. Schram (University of Washington) and C. E. Schweitzer (Kent State University) for their valuable reviews; we are particularly indebted to P. J. Orr for his extremely careful review and S. T. Ahyong, whose suggestions greatly improved the systematics section. JAC gratefully acknowledges financial support from a Palaeontological Association Sylvester-Bradley Award. The work of $\mathrm{CHJH}$ was financed by a European Union Marie Curie Fellowship (Contract no. ERBFMBICT 983257).

\section{REFERENCES}

Ahyong, S. T. 2001. Revision of the Australian stomatopod Crustacea. Records of the Australian Museum, Supplement, Number 26, 326 p.

Ahyong, S. T. 2005. Phylogenetic analysis of the Squilloidea (Crustacea: Stomatopoda). Invertebrate Systematics, 19:189-208.

Ahyong, S. T. AND C. HARLing. 2000. The phylogeny of the stomatopod Crustacea. Australian Journal of Zoology, 48:607-642.

Brooks, W. K. 1886. Report on the Stomatopoda collected by H.M.S. Challenger during the years 1873-76. The Voyage of the H.M.S. Challenger. Zoology, 16:1-116.

Caldwell, R. L. And H. Dingle. 1976. Stomatopods. Scientific American, 234(1):80-89. 
Calman, W. T. 1904. On the classification of the Crustacea Malacostraca. Annals and Magazine of Natural History, 7(13):144-158.

HoF, C. H. J. AND D. E. G. BRIGGS. 1997. Decay and mineralization of mantis shrimps (Stomatopoda: Crustacea) - a key to their fossil record. Palaios, 12:420-438.

HoF, C. H. J. AND F. R. Schram. 1998. Stomatopods (Crustacea: Malacostaca) from the Miocene of California. Journal of Paleontology, 72:317-331.

Jenner, R. A., C. H. J. Hof, And F. R. Schram. 1998. Palaeo- and Archaeostomatopods (Hoplocarida, Crustacea) from Bear Gulch Limestone, Mississippian (Namurian), of Central Montana. Contributions to Zoology, 67:155-185.

KEMP, S. 1911. Preliminary descriptions of new species and varieties of Crustacea Stomatopoda of the Indo-Pacific region, based on the collection in the Indian Museum. Records of the Indian Museum, 6:93-100.

KEMP, S. 1913. An account of the Crustacea Stomatopoda of the Indo-Pacific region, based on the collection in the Indian Museum. Memoirs of the Indian Museum, 4:1-217.

Latreille, P. A. 1802-1803. Histoire Naturelle, Générale et Particulière, des Crustacés et des Insectes, Volume 3. F. Dufart, Paris, 468 p.

LAtreille, P. A. 1806. Genera Crustaceorum et Insectorum Secundum Ordinem Naturalem in Familias Disposita, Iconibus Exemplisque Plurimis Explicata, Volume 1, Parisiis et Argenorati (Amand Koenig), 302 p.

LAtreille, P. A. 1817. Les crustacés, les arachnides et les insectes. In G. Cuvier, La Règne Animal Distribué d'après son Organisation, pour Servir de Base à l'Histoire Naturelle des Animaux et d'Introduction à l'Anatomie Comparée, edition 1, Pt. 3. Déterville, Paris, 653 p.
Latreille, P. A. 1825. Familles Naturelles du Règne Animal, Exposées Succinctement et dans un Ordre Analytique, avec l'Indication de leurs Genres. J. B. Baillière, Paris, 570 p.

Manning, R. B. 1968. A revision of the family Squillidae (Crustacea: Stomatopoda), with the description of eight new genera. Bulletin of Marine Science, 18:105-142.

Manning, R. B. 1969. Stomatopod Crustacea of the Western Atlantic. University of Miami Press, Coral Gables, Florida, $380 \mathrm{p}$.

MANNING, R. B. 1977. Preliminary accounts of five new genera of stomatopod crustaceans. Proceedings of the Biological Society of Washington, 90:420 423.

Manning, R. B. 1980. The superfamilies, families, and genera of Recent stomatopod Crustacea, with diagnoses of six new families. Proceedings of the Biological Society of Washington, 93:362-372.

Manning, R. B. 1995. Stomatopod Crustacea of Vietnam: The Legacy of Raoul Serène. Crustacean Research, Special Number 4. The Carcinological Society of Japan, Tokyo, 339 p.

Rathbun, M. J. 1932. Fossil Pinnotherids from the California Miocene. Journal of the Washington Academy of Sciences, 22:411-413.

Rowell, H. C. 1981. Biostratigraphy of Monterey Formation, Palos Verde Hills, Southern California. Association of American Petroleum Geologists Bulletin, 65:982.

Schram, F. R. 1986. Crustacea. Oxford University Press, New York, 606 p.

Watling, L., C. H. J. Hof, And F. R. Schram. 2000. The place of the Hoplocarida in the malacostracan pantheon. Journal of Crustacean Biology, 20:1-11.

ACCEPTED 26 JANUARY 2007 